\section{Multi-level analysis of environmental disclosure by Brazilian and German firms}

\author{
Karla Vanessa Nogueira Maia Amorim ${ }^{1}$ (1) \\ Marcelle Colares Oliveira ${ }^{2}$ (it) \\ Manuel Salgueiro Rodrigues Júnior ${ }^{3}$
}

Received:

12/21/2019

Approved:

$11 / 10 / 2020$

Editor in charge:

Prof. Dr. João Mauricio Gama

Boaventura

\section{Evaluation process:}

Double-blind review

\begin{abstract}
Purpose: The influence of macro-, meso-, and micro-level factors on corporate environmental disclosure was evaluated for a sample of German and Brazilian firms belonging to environmentally sensitive sectors.

Theoretical framework: The macro-level analysis was based on the national business system approach (Whitley, 1999), the meso-level analysis was based on business sector (Campbell, 2007; Ederington \& Minier, 2003), and the microlevel analysis was based on endogenous corporate variables (Sánchez, Domínguez, \& Álvarez, 2011; Waddock \& Graves, 1997).
\end{abstract}

Methods: Data covering the 2014-2016 period were retrieved from sustainability and financial reports issued by firms in six sectors (aviation, energy, timber, paper, chemicals, and textiles) and subjected to panel data analysis and hierarchical linear modeling.

Results: Our results confirm the hypothesized association between environmental disclosure and national culture. Business sector was also a significant factor, but the strongest determinants were firm size and profitability.

Practical and social implications: The endogenous (micro-level) variables displayed the greatest explanatory power for environmental disclosure in both countries. Investigators in this field are therefore advised to direct more attention to factors at this level.

Contributions: Hierarchical linear modeling increased our ability to evaluate the factors influencing corporate environmental practices.

Keywords: National business system. Multi-level analysis. Environmental disclosure.

1. Unifanor Wyden University Center, Centro de Negócios, Fortaleza, Brazil

2. Universidade Federal do Ceará, PPAC, Fortaleza, Brazil

3. Universidade Estadual do Ceará, Centro de Estudos Sociais Aplicados, Fortaleza, Brazil

How to cite:

Amorim, K., Oliveira, M., Rodrigues Jr., M. (2021). Multi-level analysis of environmental disclosure by Brazilian and German firms. Revista Brasileira de Gestâo de Negócios, 22(1), firstpage-lastpage.

\section{Reviewers:}

Darliane Ribeiro Cunha. One of the reviewers decided not to disclose his/ her identity.

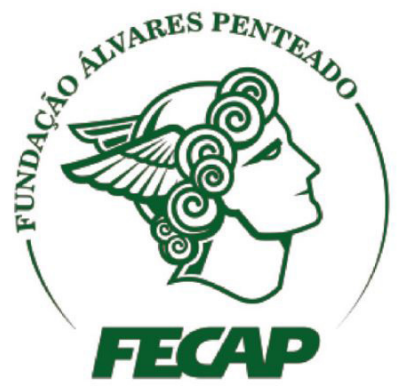

Revista Brasileira de Gestáo de Negócios

https://doi.org/10.7819/rbgn.v23i2.4102 


\section{Introduction}

The 1970s saw the emergence of collective concerns which would eventually coalesce into the concept of corporate environmental and social responsibility (CSR) (Kolk, 2010). These concerns were initially social in nature, but in 1990, once environmental issues had become more widely acknowledged, they culminated in the so-called 'triple bottom line' - a social, environmental, and economic framework. As pointed out by Kraemer (2001), this new understanding of the role of private enterprises has increased external pressure on firms. In response, many have adopted CSR disclosure as a form of accountability.

With the growing ecological awareness of government agents, company executives, and society at large, environmental preservation initiatives have been woven into the patchwork of corporate strategy. Thus, more and more firms make public their stance on environmental issues through disclosure in corporate reports (Kraemer, 2001; Ribeiro, Bellen, \& Carvalho, 2011).

CSR disclosure may take different forms in different countries due to the distance between expectations and social reality (Grecco, Milani Filho, Segura, Sanchez, \& Dominguez, 2013). Moreover, Abreu, Cunha, and Barlow (2015) and Soares, Sá de Abreu, Pinheiro Marino, and Rebouças (2020) believe the institutional environment also determines how firms respond to social responsibility demands. In fact, Matten and Moon (2008) see country-level differences in CSR as reflecting institutions historically rooted in national business systems (NBSs) in the long term. In other words, firms develop their social and environmental policies under the influence of the national institutional environment.

Investigations into how country-level differences affect business practices can be highly rewarding. In this study, we chose to evaluate environmental disclosure by Brazilian and German firms in view of the stark difference between these two countries. The World Bank Group classifies Germany as 'high-income' and Brazil as 'upper middle income' (World Bank, 2018), but many other important differences apply, as we shall see in the Methods section.

Based on the concept of NBS, Whitley's framework (1999) may be used to analyze the influence of the institutional environment on firms in their respective countries. Whitley divided the NBS into four subsystems: political, financial, cultural, and educational/labor. Some authors (e.g., Jensen \& Berg, 2012) add an economic system to the classification. Several investigators, including Matten and Moon (2008), Jensen and Berg (2012), Ioannou and Serafeim (2012), and Soares, Sá de Abreu, Pinheiro Marino, and Rebouças (2020), have found a significant association between the NBS and CSR using Whitley's framework (1999).

In an attempt to understand what drives business organizations to adopt CSR practices, Aguilera, Rupp, Williams, and Ganapathi (2005) and Lattemann, Fetscherin, Alon, Li, and Schneider (2009), among others, have used multilevel models to evaluate factors at the micro (firm), meso (sector), and macro (country) level.

In the present study, the macro level is represented by the NBS, while the meso level was included to determine to what extent the business sector (or industry) influences the level of corporate environmental disclosure. This level of influence was studied by Young and Marais (2012), Li, Fetscherin, Alon, Lattelmann, and Yeh (2010), Silveira and Pfitscher (2013), Gamerschlag, Möller, and Verbeeten, (2011), Amorim (2015), Viana Junior and Crisóstomo (2019), and Campbell (2007), all of whom found an association between sector and disclosure, whether environmental, socioenvironmental, or overall CSR.

The micro level involves aspects of the organization itself which may affect the level of environmental disclosure. Institutional pressure and company variables interact to determine the adoption of environmental management practices. Managers' perceptions of institutional pressure depend on the characteristics of each firm (Delmas \& Toffel, 2004). Factors such as company size, CEO/ chairman duality, and the participation of external directors on the board can also influence the level of CSR disclosure, as shown by Lattemann et al. (2009), Mascena, Barakat, Isabella, and Fischmann (2020), and Li et al. (2010).

The purpose of the present study was to evaluate the influence of variables at three levels (macro, meso, and micro) on environmental disclosure - one of the pillars of the triple bottom line. The study was exploratory, considering the scarcity of research conducted in the area, and used a multi-level approach to compare firms from two countries with regard to environmental disclosure. The study is intended to 
generate new knowledge, subsidize discussions, and support future research efforts.

Assuming environmental corporate practices are influenced by the NBS, business sector, and firm variables, we set out to answer the following question: How do factors at the macro (NBS), meso (sector), and micro (firm) level affect the level of environmental disclosure by Brazilian and German firms in environmentally sensitive sectors?

In other words, our aim was to evaluate the influence of factors at multiple levels on the disclosure of environmental practices adopted by firms in Brazil and Germany. To do so, we measured the environmental performance of the sampled firms with GRI indicators (Global Reporting Initiative, 2017) and the NBS indicators proposed by Whitley (1999), Matten and Moon (2008), and Jensen and Berg (2012). We also identified environmentally sensitive sectors and company characteristics for both countries.

Our results provide a significant input to the current understanding on a whole set of factors that potentially influence the adoption and subsequent disclosure of corporate practices related to the environment - a hotly debated topic among academics due to its direct bearing on the management of natural resources. In addition, the application of the hierarchical linear model (HLM) method to a social science problem, assessing the explanatory power of factors at multiple levels, represents a significant advance in this field of study.

Several national and international authors have investigated the impact of institutional, sector-related, and organizational factors on the environment (de Mascena, Barakat, Isabella \& Fischmann 2020; Kolk, 2010; Abreu, Cunha \& Barlow, 2015; Soares et al. 2020; Matten \& Moon, 2008; Lattemann et al., 2009; Amorim, 2015; Delmas \& Toffel, 2004; Viana Junior \& Crisóstomo, 2019), but the present study takes one step further by comparing the institutional environments of two widely different economies (Germany and Brazil) while evaluating disclosure-related factors at multiple levels (country, sector, firm).

\section{Theoretical framework}

\section{I Influence at the macro level (NBS)}

Organizational characteristics to some extent determine how institutional pressure is perceived by managers. Examples include companies' financial and environmental performance, organizational structure, and strategic policies (Delmas \& Toffel, 2004).

The concept of NBS was proposed by Whitley (1999) in order to investigate national institutional factors. As explained by Tempel and Walgenbach (2007), knowledge of the NBS makes it possible to show to what extent firms are influenced by the institutional environment.

\section{I.I The financial system}

In this study we analyzed the financial system from the perspective of financial market development, using the Global Competitiveness Index (GCI) of the World Economic Forum (WEF, 2018).

According to Jensen and Berg (2012), in economies with high ownership dispersion, such as market-oriented financial systems, firms are controlled by anonymous investors. This increases the need for both financial and CSR disclosure (Mayer, 1990; Jensen \& Berg, 2012).

Moreover, as pointed out by Matten and Moon (2008), since the stock market is the most important source of corporate funds, firms are required to display a high level of transparency and accountability to attract investors. Based on these considerations, the following hypothesis was formulated:

H1a: The level of environmental disclosure is positively associated with financial market development.

\section{I.2 The political system}

We analyzed the political system using the WEF indicator described in GCI: Institutions. The indicator measures the development of private and public institutions in a country. This development is proxied by the level of corruption, among other aspects. The more widespread corruption is, the less developed the institutions are.

Likewise, Lattemann et al. (2009) concluded that in environments with high levels of corruption, firms are unable to maintain high levels of CSR and therefore tend to engage in less disclosure of this type.

Ioannou and Serafeim (2012) also made the claim (supported by our results) that firms in countries with high levels of corruption engage in less CSR-related disclosure. According to those authors, in countries with a predominantly neoclassical ethos, 
projects benefiting stakeholders in detriment to the owners (such as CSR initiatives) are considered a waste of shareholder wealth. In such environments, laws for investor protection may be created, thereby discouraging investments in CSR. Based on this, the following hypothesis was formulated:

H1b: The level of environmental disclosure is positively associated with national institutional development.

\section{I.3 The education and labor system}

We used two WEF indicators to assess the education and labor system: higher education and training, and labor market efficiency.

Matten and Moon (2008) found that major European business schools or institutions of higher learning offer CSR disciplines, often as mandatory modules. This would go a long way to explaining the high level of CSR observed in Europe.

Interestingly, Meireles (2014) concluded that firms in countries with overall high levels of schooling engage in more CSR disclosure. In her study, the secondary education enrollment rate was positively associated with the level of CSR disclosure. This led to the formulation of our third hypothesis:

H1c: The level of environmental disclosure is positively associated with higher education and training.

The seventh GCI pillar (labor market efficiency) has 'cooperation in labor-employer relations' as one of its components. This was used by Soares et al. (2020) to establish the relationship between CSR disclosure and the quality of labor-employer relations. In their study, cooperation was greater in Canada than in Brazil with regard to both social and environmental disclosure. Thus, the following hypothesis was formulated:

H1d: The level of environmental disclosure is positively associated with the development of the labor market.

\section{I.4 The cultural system}

Recently, Wronski and Klann (2019) concluded that national culture has an impact on accounting information quality, and Sanchez, Ballesteros, and Aceituno (2016) correlated this influence with CSR practices. In our study, culture was proxied by three of the indicators proposed by Hofstede (1983).

Power distance is the degree to which members of an organization or society expect power to be shared unequally. The greater the distance, the more autocratic the leadership. When the participation of workers is low, transparency is compromised and the level of disclosure also tends to be low (Hofstede, 1983; Gray, 1988).

Unsurprisingly, in a study of 1598 firms from 20 countries, covering the 2004-2010 period, Sanchez, Ballesteros, and Aceituno (2016) found that a smaller power distance was synonymous with greater CSR disclosure. Based on these observations, we formulated the hypothesis below:

H1e: The level of environmental disclosure is negatively associated with power distance.

In societies where people are particularly keen to control the future out of fear of the unknown, anxiety is a common affliction. This leads to the emergence of institutions empowered to create laws and regulations capable of reducing risk (Hofstede, 1983).

As shown by Gray (1988), societies with low levels of uncertainty avoidance have a relaxed atmosphere in which deviations from good practices are more easily tolerated, while societies with strong aversion to uncertainty tend to apply a rigid code of conduct. The latter may feel a need to limit disclosure in order to avoid conflicts and maintain security.

Orij (2010) studied 600 firms from 22 countries to evaluate the association between cultural aspects and CSR disclosure. A significant negative relationship was found between uncertainty avoidance and the dependent variable CSR disclosure. This made it possible to formulate the following hypothesis:

H1f: The level of environmental disclosure is negatively associated with uncertainty avoidance.

In collectivist societies, people are integrated into strong, cohesive in-groups supported by indirect action and communication. In contrast, conflicts are not avoided in individualistic societies. For example, a confrontation between German directness and Brazilian indirectness would lead to considerable conflict (Bolacio Filho, 2012)

According to Hofstede (1983), people in highly individualistic societies are only supposed to look after themselves and their immediate family, forming weak bonds with outsiders, whereas people in highly collectivist societies expect to be taken care of in exchange for unquestioning loyalty.

Similarly, firms headquartered in individualistic environments tend to be reluctant to disclose information, including environmental information (Jensen \& Berg, 
2012). On the other hand, Sanchez et al. (2016) found that firms in collectivist environments engage in greater CSR disclosure due to their closer ties to society. Likewise, Wronski and Klann (2019) believe collectivist countries favor accounting conservatism, resulting in higher information quality.

Using Hofstede's indicator of individualism vs. collectivism (Hofstede, 1983), according to which a higher value means greater individualism, the following hypothesis was formulated:

H1g: The level of environmental disclosure is negatively associated with individualism.

\section{I.5 The economic system}

Voluntary disclosure is more common in developed than developing countries, especially in the area of CSR (Jensen \& Berg, 2012). This is supported by Meireles (2014), who found a correlation between per capita GDP (a proxy for economic development) and CSR disclosure levels. Baughn, Bodie, and McIntosh (2007) also concluded that the richer the country is, the more attention is given to CSR.

This agrees with the results of Li et al. (2010), who observed a significant association between per capita GDP and CSR disclosure, and in a study by Baughn et al. (2007) both social and environmental disclosure were significantly correlated.

A comparative study of 142 companies from developed and developing countries revealed a positive correlation between GDP and firms with ISO 14001 certification. In other words, firms in more economically developed nations invest more in the implementation of environmental management systems (Neumayer \& Perkins, 2004).

However, in the opinion of Lim and Tsutsui (2012), it is hypocritical on the part of many developed countries to demand adherence to CSR practices by firms in developing economies while protecting their own industries from overly rigorous enforcement of the same. Based on these considerations, we formulated the hypothesis below:

$\boldsymbol{H 1 h}$ : The level of environmental disclosure is positively associated with macroeconomic development.

\subsection{Influence at the meso level (sector)}

At the meso level, during economic downturns, firms may decide to reduce voluntary spending on CSR initiatives (Campbell, 2007), although firms in highly unionized industrial environments may be under pressure to maintain labor-related CSR practices (Ederington \& Minier, 2003).

Ownership concentration has also been shown to have a positive impact on socioenvironmental disclosure in the Brazilian setting (Viana Junior \& Crisóstomo, 2019). The authors pointed out that belonging to a sector that is potentially aggressive to the environment and being listed in the Corporate Sustainability Index also has a positive influence.

Gamerschlag, Möller, and Verbeeten (2011) and Amorim (2015) found environmental disclosure to be greater in the energy sector than in other sectors, due to external pressure. This is explained by Silveira and Pfitscher (2013), who argue that sectors exploiting natural resources are expected to offset this by adopting measures to reduce the impact of their activity on the environment.

In their study on environmental disclosure by firms headquartered in BRICS countries, Li et al. (2010) observed the highest levels of disclosure in the manufacturing industry.

Young and Marais (2012) concluded that French and Australian firms engaged in the most CSR disclosure in high-risk sectors, probably in response to strong institutional pressure. This led to the following hypothesis:

H2: The level of environmental disclosure is influenced by the sector to which a firm belongs.

\subsection{Influence at the micro level (firm)}

In many previous investigations (Soares et al. 2020; Belkaoui \& Karpik, 1989; Sánchez, Domínguez, \& Álvarez, 2011; Grecco et al., 2013; Boesso \& Kumar, 2007), the variable 'firm size' has been shown to correlate positively with corporate disclosure. Due to their greater visibility, large firms are expected to maintain a high level of disclosure, on pain of losing legitimacy (Grecco et al., 2013).

In a sample of Italian and US firms, Boesso and Kumar (2007) identified 'firm size' and (somewhat less so) 'sector' as determinants of disclosure. Likewise, Schreck and Raithel (2018) reported a significant association between CSR (expressed as social and environmental disclosure) and firm size and visibility 
in a sample of 280 firms operating in environmentally sensitive sectors.

As explained by Agency Theory, large firms looking to attract external capital at low cost should invest in voluntary disclosure, attenuating the problem of information asymmetry (Sánchez et al., 2011).

Large firms are more exposed to public scrutiny and therefore tend to disclose more information. They also have the means to collect, analyze, and publish information at lower cost (Alsaeed, 2006). Finally, Botosan (1997) concluded that the more information a firm discloses, the greater the prospects of obtaining funds at low cost. These considerations were the basis of the following hypothesis:

H3a: The level of environmental disclosure is positively associated with firm size.

Board independence depends on the percentage of participation of external directors and on the existence of CEO/chairman duality (Sánchez et al., 2011). As might be expected, in a study of 287 firms traded on the B3, de Mascena, Barakat, Isabella, and Fischmann (2020) found a positive association between board independence and GRI-related information disclosure.

Along the same line of reasoning, Li et al. (2010) found that large firms in typically law-abiding societies engage in more CSR disclosure and have stronger corporate governance, due among other things to the absence of $\mathrm{CEO} /$ chairman duality and the greater percentage of external directors on the board. In view of the above, the following hypothesis was formulated:

H3b: The level of environmental disclosure is negatively associated with $\mathrm{CEO} /$ chairman duality.

Orlitzky, Louche, Gond, and Chapple (2015) believe that firms with poor financial performance are less likely to engage in CSR-related practices than highly profitable firms because of the additional resources required to invest in such initiatives (Waddock \& Graves, 1997).

Based on the level of voluntary disclosure by firms in Saudi Arabia, Alsaeed (2006) hypothesized that firms with high returns on equity tend to engage in more disclosure, but the observed difference was not statistically significant. Using the variable return on assets, Belkaoui and Karpik (1989) and Agyei-Mensah (2017) found a positive and significant association between performance and CSR disclosure. These results led to the formulation of the following hypothesis:
H3c: The level of environmental disclosure is positively associated with financial performance.

\section{Methods}

In this quantitative and descriptive desk study, secondary data were retrieved from sustainability and financial reports, or from integrated reports when available, covering the 2014-2016 period. Thirty-four environment-related indicators from the GRI G4 guidelines were used. Environmental information was subjected to content analysis. The information was converted to numerical data using the model proposed by Fischer and Sawczyn (2013).

Germany and Brazil were chosen for comparison in this study because of their stark institutional differences. According to BMWI (2016), the German economy grew by $1.6 \%$ in both 2014 and 2015 , with heavy investments in research, science, and education. Unemployment rates fell in the 2014-2015 period. Changes in production and renewable energy use are believed to have made the country more competitive. Currently, Germany is facing the serious challenges of an ageing population and accelerated technological change.

Between 2003 and 2014, 29 million Brazilians were lifted above the poverty line, inequality was reduced, and per capita income increased, especially among the poor. However, this was followed by a downturn in 2015 , with a stagnation of efforts to reduce poverty and inequality. An economic deficit of 3.8\% was registered in 2015, and annual inflation soared to $10.67 \%$ (World Bank, 2016).

Following the example of Cho and Patten (2007), the following sectors were considered environmentally sensitive: oil extraction, paper milling, chemical products, petroleum refining, and metals. Other potentially aggressive sectors include aviation (IPCC, 1999), textiles (Santos, 1997), energy (Silveira \& Pfitscher, 2013), and timber (Souza \& Ribeiro, 2004). The sectors evaluated in this study (aviation, energy, timber, paper, chemicals, textiles) are listed as environmentally sensitive by the stock markets of both countries: the Frankfurt Stock Exchange and the Brazil Stock Exchange and Over-the-Counter Market (B3), respectively. Table 1 shows the sample distributed among sectors and according to each country. 
Table 1

Sampled firms according to sector.

\begin{tabular}{ccc}
\hline SECTOR & GERMANY & BRAZIL \\
\hline Aviation & 3 & 2 \\
Energy & 11 & 25 \\
Timber & 1 & 2 \\
Paper & 2 & 5 \\
Chemicals & 14 & 7 \\
Textiles & 9 & 12 \\
TOTAL & 40 & 53 \\
\hline
\end{tabular}

The sample included 93 firms. Information was collected for 34 environmental GRI variables, covering a three-year period (2014-2016), and the evaluation criteria of Fischer and Sawczyn (2013) was used, generating 56,916 numerical values (93 firms x 34 indicators x 6 criteria $\times 3$ years) for statistical analysis.

The micro-level analysis included the variables 'CEO/chairman duality,' 'annual profit/loss,' 'equity,' and 'total assets,' adding 1,116 numerical values (93 firms $\mathrm{x} 4$ variables $\mathrm{x} 3$ years) to the analysis. The macro-level analysis included 8 NBS variables, totaling 48 numerical values ( 8 variables $\mathrm{x} 2$ countries $\mathrm{x} 3$ years).

\section{I Dependent variable}

In this study we adopted the environmental subcategories of the GRI G4 in order to quantify disclosure. Scoring was performed as proposed by Fischer and Sawczyn (2013) and replicated by Silva (2017) and Marino (2016).

The Fischer and Sawczyn model (2013) assigns a score between 0 and 6 to each subcategory. A 0 score is assigned when no disclosure is carried out, while the presence of each of the following items adds 1 point to the total: any disclosure of absolute or relative performance; comparison with performance of peers/rivals in the sector; comparison with performance of previous periods; performance relative to targets; presentation of performance in normalized form; and performance at disaggregate level (Table 2).

\subsection{Independent variables}

The independent or explanatory variables (Table 3) were included in the regression model to correlate national institutional variables (Whitley, 1999; Matten \& Moon, 2008) with indicators covering five
Table 2

Scoring criteria for GRI G4 subcategories.

\begin{tabular}{lc}
\hline \multicolumn{1}{c}{ Item } & Score \\
\hline No disclosure & 0 \\
Any amount of absolute or relative figures & 1 \\
Comparison with peers/rivals/sector & +1 \\
Comparison with previous periods & +1 \\
Performance relative to targets & +1 \\
Presentation of performance in normalized form & +1 \\
Performance at disaggregate level & +1 \\
Maximum score per subcategory & 6 \\
\hline Note. Source: “The relationship between corporate social \\
performance and corporate financial performance and the \\
role of innovation: evidence from German listed firms”. T. \\
M. Fischer, \& A. A. Sawczyn, (2013). Journal of Management \\
Control, 24(1), 27-52.
\end{tabular}

systems (political, financial, education/labor, cultural, economic).

In addition, a dummy variable was used to indicate the country ( $0=$ Brazil; $1=$ Germany).

Firm size was expressed as in Soares et al. (2020), using the natural logarithm of the firm's total assets (LnTA) in BRL. Amounts in other currencies were converted to BRL using the rate on the day the balance sheet was published.

Board independence corresponded to the absence (0) or presence (1) of CEO/chairman duality, while financial performance was expressed as return on assets (ROA). Table 4 shows the micro- and meso-level variables analyzed:

\subsection{Empirical model}

The statistical analyses were performed using the STATA (Data Analysis and Statistical Software) software. The resulting empirical regression model for the panel data used to test the study hypotheses is illustrated by Equations 1-9 (the equation number corresponds to the statistical model presented in Table 5):

$$
\mathrm{GRI}_{\mathrm{it}}=\alpha_{0}+\beta_{11}\left(\operatorname{LnAT}_{\mathrm{it}}\right)+\beta_{14}\left(\mathrm{CEO}_{\mathrm{it}}\right)+\beta_{15}\left(\mathrm{ROA}_{\mathrm{it}}\right)+\varepsilon_{\text {it }}
$$

$\mathrm{GRI}_{\mathrm{it}}=\alpha_{0}+\beta_{1}\left(\mathrm{FIN}_{\mathrm{it}}\right)+\beta_{11}\left(\operatorname{LnAT}_{\mathrm{it}}\right)+\beta_{14}\left(\mathrm{CEO}_{\mathrm{it}}\right)+\beta_{15}\left(\mathrm{ROA}_{\mathrm{it}}\right)+\varepsilon_{\mathrm{it}}$

$\mathrm{GRI}_{\mathrm{it}}=\alpha_{0}+\beta_{2}\left(\mathrm{POL}_{\mathrm{it}}\right)+\beta_{11}\left(\mathrm{LnAT}_{\mathrm{it}}\right)+\beta_{14}\left(\mathrm{CEO}_{\mathrm{it}}\right)+\beta_{15}\left(\mathrm{ROA}_{\mathrm{it}}\right)+\varepsilon_{\mathrm{it}}$ 
Table 3

\section{Macro-level variables (NBS).}

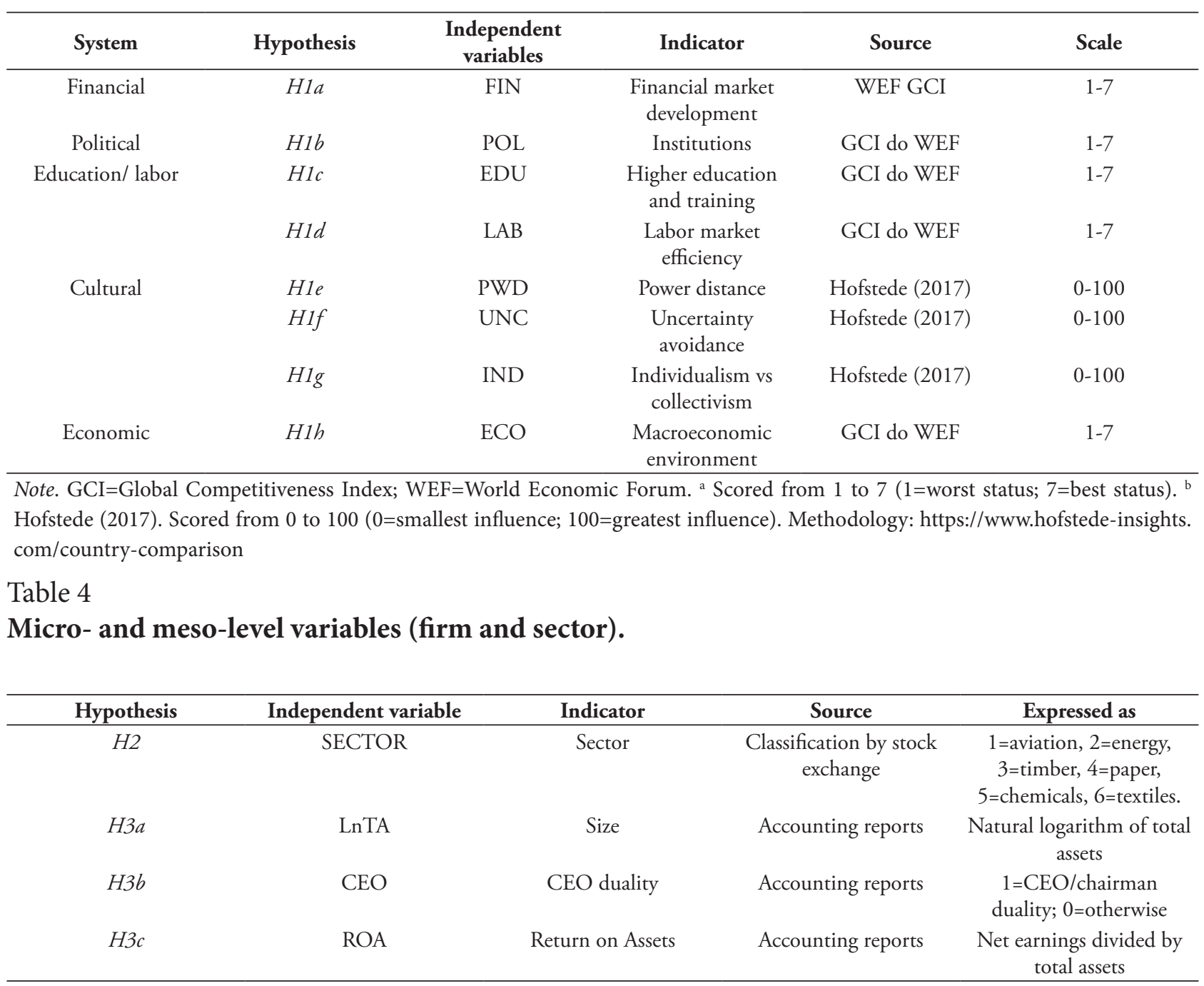

$\mathrm{GRI}_{\mathrm{it}}=\alpha_{0}+\beta_{3}\left(\mathrm{EDU}_{\mathrm{it}}\right)+\beta_{11}\left(\mathrm{LnAT}_{\mathrm{it}}\right)+\beta_{14}\left(\mathrm{CEO}_{\mathrm{it}}\right)+\beta_{15}\left(\mathrm{ROA}_{\mathrm{it}}\right)+\varepsilon_{\mathrm{it}}$

$\mathrm{GRI}_{\mathrm{it}}=\alpha_{0}+\beta_{4}\left(\mathrm{TRA}_{\mathrm{it}}\right)+\beta_{11}\left(\mathrm{LnAT}_{\mathrm{it}}\right)+\beta_{14}\left(\mathrm{CEO}_{\mathrm{it}}\right)+\beta_{15}\left(\mathrm{ROA}_{\mathrm{it}}\right)+\varepsilon_{\text {it }}(5)$

$\mathrm{GRI}_{\mathrm{it}}=\alpha_{0}+\beta_{5}\left(\mathrm{POD}_{\mathrm{it}}\right)+\beta_{11}\left(\mathrm{LnAT}_{\mathrm{it}}\right)+\beta_{14}\left(\mathrm{CEO}_{\mathrm{it}}\right)+\beta_{15}\left(\mathrm{ROA}_{\mathrm{it}}\right)+\varepsilon_{\mathrm{it}}$

$\mathrm{GRI}_{\mathrm{it}}=\alpha_{0}+\beta_{6}\left(\mathrm{INC}_{\mathrm{it}}\right)+\beta_{11}\left(\mathrm{LnAT}_{\mathrm{it}}\right)+\beta_{14}\left(\mathrm{CEO}_{\mathrm{it}}\right)+\beta_{15}\left(\mathrm{ROA}_{\mathrm{it}}\right)+\varepsilon_{\mathrm{it}}$

$\mathrm{GRI}_{\mathrm{it}}=\alpha_{0}+\beta_{7}\left(\mathrm{IND}_{\mathrm{it}}\right)+\beta_{11}\left(\mathrm{LnAT}_{\mathrm{it}}\right)+\beta_{14}\left(\mathrm{CEO}_{\mathrm{it}}\right)+\beta_{15}\left(\mathrm{ROA}_{\mathrm{it}}\right)+\varepsilon_{\mathrm{it}}$

$\mathrm{GRI}_{\mathrm{it}}=\alpha_{0}+\beta_{8}\left(\mathrm{ECO}_{\mathrm{it}}\right)+\beta_{11}\left(\mathrm{LnAT}_{\mathrm{it}}\right)+\beta_{14}\left(\mathrm{CEO}_{\mathrm{it}}\right)+\beta_{15}\left(\mathrm{ROA}_{\mathrm{it}}\right)+\varepsilon_{\mathrm{it}}$
Our results were also subjected to multivariate analysis, as in Orlitzky et al. (2015) and Marino (2016). The HLM method was used to test for covariance between the three levels of influence (NBS, sector, and firm). The HLM model below was estimated in order to determine the explanatory power at each level, i.e., the percentage of variance in environmental disclosure attributable to the NBS, sector, and firm:

$$
\begin{aligned}
& \mathrm{GRI}_{\mathrm{ijkt}}=\alpha_{0}+\beta_{1}\left(\mathrm{FIN}_{\mathrm{it}}\right)+\beta_{2}\left(\mathrm{POL}_{\mathrm{it}}\right)+\beta_{3}\left(\mathrm{EDU}_{\mathrm{it}}\right)+ \\
& \beta_{4}\left(\mathrm{TRA}_{\mathrm{it}}\right)+\beta_{5}\left(\mathrm{POD}_{\mathrm{it}}\right)+\beta_{6}\left(\mathrm{INC}_{\mathrm{it}}\right)+ \\
& \beta_{7}\left(\mathrm{IND}_{\mathrm{it}}\right)+\beta_{8}\left(\mathrm{ECO}_{\mathrm{it}}\right)+\beta_{10}\left(\mathrm{SETOR}_{\mathrm{it}}\right)+ \\
& \beta_{11}\left(\mathrm{LnAT}_{\mathrm{it}}\right)+\beta_{14}\left(\mathrm{CEO}_{\mathrm{it}}\right)+\beta_{15}\left(\mathrm{ROA}_{\mathrm{it}}\right)+\mathrm{Ci}+\varepsilon_{\mathrm{it}}
\end{aligned}
$$

$\mathrm{Ci}=\tau+\varepsilon+\mathrm{r}+\mathrm{u}$ 
Table 5

Estimation of panel data with random effects.

\begin{tabular}{|c|c|c|c|c|c|c|c|c|c|}
\hline Variable & Model 1 & Model 2 & Model 3 & Model 4 & Model 5 & Model 6 & Model 7 & Model 8 & Model 9 \\
\hline \multirow[t]{2}{*}{$\mathrm{CEO}$} & 1.527 & 1.619 & 1.421 & 1.551 & 1.511 & 1.325 & 1.325 & 1.325 & 1.573 \\
\hline & $(2.29)$ & $(2.29)$ & $(2.29)$ & $(2.29)$ & $(2.29)$ & $(2.28)$ & $(2.28)$ & $(2.28)$ & $(2.29)$ \\
\hline \multirow[t]{2}{*}{ LnTA } & $4.951^{*}$ & $4.936^{*}$ & $5.086^{*}$ & $4.961^{*}$ & $5.016^{*}$ & $5.231^{*}$ & $5.231^{*}$ & $5.231^{*}$ & $4.913^{*}$ \\
\hline & $(0.57)$ & $(0.57)$ & $(0.57)$ & $(0.56)$ & $(0.58)$ & $(0.58)$ & $(0.58)$ & $(0.58)$ & $(0.57)$ \\
\hline \multirow[t]{2}{*}{ ROA } & $12.069^{*}$ & $12.204^{*}$ & $12.154^{*}$ & $12.100^{*}$ & $12.024^{*}$ & $12.032^{*}$ & $12.032^{*}$ & $12.032^{*}$ & $12.051^{*}$ \\
\hline & $(3.71)$ & $(3.70)$ & $(3.72)$ & $(3.74)$ & $(3.72)$ & $(3.70)$ & $(3.70)$ & $(3.70)$ & $(3.72)$ \\
\hline \multirow[t]{2}{*}{ FIN } & & 1.615 & & & & & & & \\
\hline & & $(1.14)$ & & & & & & & \\
\hline \multirow[t]{2}{*}{ POL } & & & -1.378 & & & & & & \\
\hline & & & (1.18) & & & & & & \\
\hline \multirow[t]{2}{*}{ EDU } & & & & -0.172 & & & & & \\
\hline & & & & $(0.73)$ & & & & & \\
\hline \multirow[t]{2}{*}{ LAB } & & & & & -1.208 & & & & \\
\hline & & & & & $(2.23)$ & & & & \\
\hline \multirow[t]{2}{*}{ PWD } & & & & & & $0.141^{* * *}$ & & & \\
\hline & & & & & & $(0.07)$ & & & \\
\hline \multirow[t]{2}{*}{ INC } & & & & & & & $0.435^{* * *}$ & & \\
\hline & & & & & & & $(0.23)$ & & \\
\hline \multirow[t]{2}{*}{ IND } & & & & & & & & $-0.165^{* * *}$ & \\
\hline & & & & & & & & (0.09) & \\
\hline \multirow[t]{2}{*}{ ECO } & & & & & & & & & 0.445 \\
\hline & & & & & & & & & $(0.73)$ \\
\hline \multirow[t]{2}{*}{ Const. } & $-95.716^{*}$ & $-102.374^{*}$ & $-93.003^{*}$ & $-95.110^{*}$ & $-92.149^{*}$ & $-109.547^{*}$ & $-132.912^{*}$ & $-93.555^{*}$ & $-97.026^{*}$ \\
\hline & $(12.69)$ & (13.49) & $(12.81)$ & $(12.95)$ & (14.30) & (14.49) & $(23.27)$ & $(12.59)$ & (12.83) \\
\hline $\mathrm{R} 2$ & 0.4367 & 0.4255 & 0.4523 & 0.4386 & 0.4449 & 0.4569 & 0.4569 & 0.4569 & 0.4295 \\
\hline Obs & 279 & 279 & 279 & 279 & 279 & 279 & 279 & 279 & 279 \\
\hline F/Wald & 96.14 & 98.74 & 98.87 & 97.29 & 96.92 & 101.86 & 101.86 & 101.86 & 96.83 \\
\hline p-value & 0.00 & 0.00 & 0.00 & 0.00 & 0.00 & 0.00 & 0.00 & 0.00 & 0.00 \\
\hline
\end{tabular}

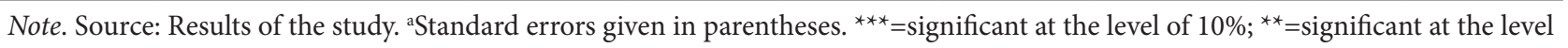
of $5 \% ;{ }^{*}=$ significant at the level of $1 \%$.

In Equation 10 above, the dependent variable (environmental disclosure) is represented by $\mathrm{GRI}_{\mathrm{ijkt}}$, where $i$ is the firm, $j$ is the country, $k$ is the sector, and $t$ is the year. The explanatory variables are the same as in the panel analysis, with the inclusion of $C i$ (which does not vary over time), representing the idiosyncrasy of the model. The $C i$ variable is defined in Equation 11 and is represented by the sum of $\tau$ (random country effect), $\varepsilon$ (random sector effect), $r$ (random firm effect), and $u$ (random residual effect).

The HLM method is an adequate tool for the analysis of repeated measures. It ranks the variables according to explanatory power. Thus, the variables identified by the model are the three variables at the top of the list of influence, or rather, the three highest levels. This same method was used by Marino (2016) and Orlitzky et al. (2017). 


\section{Results}

To better understand the behavior of the study variables in the model, we carried out a panel analysis and a hierarchical analysis, identifying the most significant determinants according to country, sector, and firm.

\section{I Panel analysis}

During the analysis of the model, a strong correlation between macro-level variables was observed, making it necessary to build a different model for each variable at this level, thereby avoiding multicollinearity. Thus, 9 models were generated (Table 5).

The Chow, Breush-Pagan, and Hausman tests were used to determine which type of effects (pooled, fixed, or random) was the most reliable for the dataset. The results identified the random effects estimator as the best option, with the level of statistical significance set at $5 \%(p<0.05)$.

The panel analysis (Table 5) indicated a good model fit since the F/Wald tests of overall significance rejected the null hypothesis. Moreover, the coefficient adjustment analysis revealed that $-45 \%$ of the variation observed for the dependent variable could be explained by fluctuations in the explanatory variables.

In our analysis of micro-level variables, $\mathrm{CEO} /$ chairman duplicity was not a significant determinant of disclosure, contrasting with the significant findings of Lattemann et al. (2009), Li et al. (2010), and Mascena, Barakat, Isabella, and Fischmann (2020). As for firm size, we estimate that a $1 \%$ increase in LnTA increased disclosure by 5 points (GRI), but performance (ROA) was the most significant variable at this level: each $1 \%$ increase in ROA corresponded to a 12-point increase in the GRI score. This pattern is well supported by the literature for both LnTA (Sánchez et al., 2011; Alsaeed,

Table 6

\section{Influence of hierarchical levels on the com- position of random effects.}

\begin{tabular}{cccc}
\hline Level & Brazil & Germany & General \\
\hline Country & $0.0 \%$ & $0.0 \%$ & $3.1 \%$ \\
Sector & $16.0 \%$ & $3.6 \%$ & $9.4 \%$ \\
Firm & $72.8 \%$ & $76.0 \%$ & $74.1 \%$ \\
Residual & $11.2 \%$ & $20.5 \%$ & $13.4 \%$ \\
\hline
\end{tabular}

2006; Botosan, 1997) and ROA (Orlitzky et al., 2015; Belkaoui \& Karpik, 1989; Agyei-Mensah, 2017).

The macro-level variables FIN, POL, EDU, LAB, and $\mathrm{ECO}$ were not significant when using the random effects approach, as opposed to previous studies on the financial/economic system (Jensen \& Berg, 2012), the political system (Ioannou \& Serafeim, 2012), the education/ labor system (Matten \& Moon, 2008; Campbell, 2007), and others.

The culture system variables PWD and UNC were positively correlated with environmental disclosure, disagreeing with the conclusions of Sanchez et al. (2016), Gray (1988), and Orij (2010), who reported a positive association for these variables. On the other hand, the correlation with IND was negative, as in the studies of Sanchez et al. (2016) and Wronski and Klann (2019).

\subsection{Hierarchical data analysis}

Table 6 shows that the contribution of 'country' was relatively small, corresponding to $3.1 \%$ of the variation observed in the dependent variable, although the individual contribution of Brazil and Germany was less than $0.1 \%$. Next in importance, 'sector' accounted for $9.4 \%$ of the variation. This is compatible with the results of Boesso and Kumar (2007), Gamerschlag et al. (2011), Amorim (2015), Silveira and Pfitscher (2013), Li et al. (2010), and Young and Marais (2012).

Micro-level (firm) variables were much more influential than meso- (sector) and macro- (country) level variables, explaining $74.1 \%$ of the variation in the GRI indicator $(72.8 \%$ for Brazil and $76.0 \%$ for Germany).

The results of the linear hierarchical model match the results of the panel analysis, showing that environmental disclosure was primarily determined by endogenous firm variables. Exogenous factors also had an impact, but this was relatively small.

\section{$4 \cdot 3$ Summary of hypotheses}

Table 7 presents a summary of the hypotheses tests. H1 (a-h) refers to the macro level (NBS), H2 to the meso level (sector), and H3 (a-c) to the micro level (firm).

The culture variables PWD (Hle) and UNC (H1f) were statistically significant, but the sign was the opposite of what was expected. Since a significant 
Table 7

Summary of hypotheses.

\begin{tabular}{|c|c|c|c|c|}
\hline \multirow{2}{*}{ Code } & \multirow{2}{*}{ Description } & \multicolumn{3}{|c|}{ Results of analyses } \\
\hline & & Significant & Association & Outcome \\
\hline$H 1 a$ & $\begin{array}{l}\text { The level of environmental disclosure is positively associated with } \\
\text { financial market development }\end{array}$ & No & None & Rejected \\
\hline$H 1 b$ & $\begin{array}{c}\text { The level of environmental disclosure is positively associated with } \\
\text { national institutional development }\end{array}$ & No & None & Rejected \\
\hline$H 1 c$ & $\begin{array}{l}\text { The level of environmental disclosure is positively associated with } \\
\text { higher education and training }\end{array}$ & No & None & Rejected \\
\hline H1d & $\begin{array}{l}\text { The level of environmental disclosure is positively associated with the } \\
\text { development of the labor market }\end{array}$ & No & None & Rejected \\
\hline H1e & $\begin{array}{l}\text { The level of environmental disclosure is negatively associated with } \\
\text { power distance }\end{array}$ & Yes & Positive & Partly accepted \\
\hline$H 1 f$ & $\begin{array}{l}\text { The level of environmental disclosure is negatively associated with } \\
\text { uncertainty avoidance }\end{array}$ & Yes & Positive & Partly accepted \\
\hline $\mathrm{HIg}$ & $\begin{array}{l}\text { The level of environmental disclosure is negatively associated with } \\
\text { individualism }\end{array}$ & Yes & Negative & Accepted \\
\hline$H 1 h$ & $\begin{array}{l}\text { The level of environmental disclosure is positively associated with } \\
\text { macroeconomic development }\end{array}$ & No & None & Rejected \\
\hline$H 2$ & $\begin{array}{l}\text { The level of environmental disclosure is influenced by the sector to } \\
\text { which a firm belongs }\end{array}$ & Yes & $\mathrm{n} / \mathrm{a}$ & Accepted \\
\hline$H 3 a$ & $\begin{array}{l}\text { The level of environmental disclosure is positively associated with firm } \\
\text { size }\end{array}$ & Yes & Positive & Accepted \\
\hline$H 3 b$ & $\begin{array}{l}\text { The level of environmental disclosure is negatively associated with } \\
\text { CEO/chairman duality }\end{array}$ & No & None & Rejected \\
\hline$H 3 c$ & $\begin{array}{l}\text { The level of environmental disclosure is positively associated with } \\
\text { financial performance }\end{array}$ & Yes & Positive & Accepted \\
\hline
\end{tabular}

Note: H1: macro-level hypotheses; H2; meso-level hypotheses; H3: micro-level hypotheses.

association with the dependent variable was found, the respective hypotheses were partly accepted.

As anticipated, the influence of the IND variable (H1g) was negative; thus, the hypothesis was accepted. The hypotheses were also accepted with regard to the micro-level variables 'firm size' $(H 3 a)$ and 'financial performance' $(H 3 c)$ and the meso-level variable 'sector' (H2), based on the results of the hierarchical analysis.

\section{Discussion}

Several aspects of the political system have been connected with corruption. Indeed, authors such as Lattemann et al. (2009), Ioannou and Serafeim (2012), and Agyei-Mensah (2017) believe CSR disclosure is negatively impacted by corruption. Nevertheless, this notion was not supported by the findings of the present study.

The education and labor system had no significant effect on disclosure either. In comparison, Soares et al. (2020) found a positive association for labor and a negative one for education. Jensen and Berg (2012) concluded that the education system was correlated with the issuance of integrated reports, while both Meireles (2014) and Lim and Tsutsui (2012) reported positive associations between education and CSR disclosure.

The positive relationship between environmental disclosure and the variables PWD and UNC contradicts the conclusions of Gray (1988) and Sanchez et al. (2016). This may be explained by the fact that, as pointed out by Soares et al. (2020), when societies feel threatened by ambiguous or unpredictable developments, due to uncertainty avoidance (as defined by Hofstede, 1983) 
they respond by creating institutions to enforce security measures.

Another cultural variable, individualism, is believed by many scholars to compromise environmental disclosure (Sanchez et al., 2016; Wronski \& Klann, 2019; Jensen \& Berg, 2012). The hypothesized negative association was confirmed in the present study.

The hypothesis regarding the macro-level variable 'macroeconomic development' was rejected due to nonsignificance. The influence was significant in other major studies (Jensen \& Berg, 2012; Baughn et al., 2007; Li et al., 2010; Neumayer \& Perkins, 2004), possibly because of differences between the proxies employed.

The HLM model revealed that disclosure is to some extent influenced by the sector to which the firm belongs. Thus, the meso level represented the second-largest influence on the dependent variable. Boesso and Kumar (2007) reported similar results for voluntary disclosure, with firm size being the strongest predictor.

Some sectors are particularly susceptible to regulatory, economic, and social pressure due to their potential impact on the human and natural environment. This may explain why disclosure was greater in the energy sector than in any other sector in three recent studies (Gamerschlag et al., 2011; Amorim, 2015; Silveira \& Pfitscher, 2013).

At the micro level, firm size was positively and significantly correlated with disclosure, as reported by Agyei-Mensah (2017) and Soares et al. (2020). According to Alsaeed (2006), Schreck and Raithel (2018), and Grecco et al. (2013), large firms have greater visibility and are therefore under greater pressure from society to act responsibly and engage in more disclosure. In addition, large firms often adopt principles of transparency in order to become more attractive to investors (Sánchez et al., 2011; Botosan, 1997).

Lattemann et al. (2009) and Li et al. (2010) found a correlation between $\mathrm{CEO} /$ chairman duplicity and CSR initiatives. They also observed a positive association between board independence and GRIbased disclosure, as did Mascena, Barakat, Isabella, and Fischmann (2020). However, with the statistical tests employed in our study, these variables were nonsignificant.

Financial performance was a significant and positive predictor of environmental disclosure, matching the results of Belkaoui and Karpik (1989) and Agyei-
Mensah (2017). As suggested by Orlitzky et al. (2015), profitable firms have more resources available for CSRrelated initiatives.

Our multi-level hierarchical analysis showed that micro-level variables (i.e. endogenous factors) were responsible for most $(74 \%)$ of the variance in environmental disclosure. The meso-level variable 'sector' explained $9.4 \%$ of the variance, while macro-level variables (NBS) accounted for only $3.1 \%$, despite the finding of a relationship between disclosure and the financial, labor, culture, and economic system.

In a study based on a 5-year dataset involving 2060 firms from 10 sectors analyzed with the HLM method, Orlitzky et al. (2015) reached conclusions similar to ours: micro-level factors had the most power (44\%) in explaining environmental disclosure, followed by the sector $(13 \%)$ and the NBS (11\%).

\section{Final considerations}

In view of the growing concern about the role played by corporations in the conservation and recovery of the environment, we evaluated multi-level factors suspected of impacting the level of environmental disclosure by Brazilian and German firms operating in sensitive sectors.

Using panel analysis and the HLM method, we estimated the ability of macro-level (NBS), meso-level (sector), and micro-level (firm) variables to explain the observed levels of disclosure.

Micro-level factors were by far the most explanatory (Germany $=76.0 \%$; Brazil $=72.8 \%)$, but only two of the three variables at this level (firm size and ROA) were significant. Contrary to expectations, the third variable (CEO/chairman duality) was nonsignificant.

The meso level (sector) was the second-most explanatory element. Finally, the institutional influence (NBS) on environmental disclosure was nearly null in the individual analysis, but reached 3.3\% when the countries were pooled. Two of the cultural variables were significant and positive (power distance and uncertainty avoidance), and one was significant and negative (individualism). The variables of the financial, political, educational/labor, and economic system had no significant impact.

Our study provides a contribution to the current debate on the factors that determine the adoption and 
disclosure of corporate environmental practices. The topic has quickly spread across the academic spectrum due to the urgency of preserving natural resources. In addition, the explanatory power of our analyses was enhanced by the use of hierarchical linear modeling, a method only recently adopted by the social sciences. The method makes it possible to evaluate influences at different levels on the same dependent variable.

We also provide support for firms looking to improve their environmental strategies to achieve a superior level of environmental performance, as acknowledged by their stakeholders.

Some limitations of the study could be considered. For example, our time series (2014-2016) was relatively short; however, sustainability and financial reports were not available outside this period for a subset of German firms. The sample was further reduced by the unavailability in some cases of the required reports for one or more years.

Future research could apply similar methods to a larger sample of countries, including both developed and emerging economies, for a more comprehensive panorama of factors at the macro level. Likewise, a wider array of sectors would increase the analysis possibilities. Finally, the study period could be extended in order to increase the accuracy of the results, especially with regard to the influence of the national business system.

\section{References}

Abreu, M. C. S., Cunha, L. T. \& Barlow, C. Y. (2015) Institutional dynamics and organizations affecting the adoption of sustainable development in the United Kingdom and Brazil. Business Ethics: A European Review, 24(1), 73-90.

Aguilera, R. V., Rupp, D. E., Williams, C. A. \& Ganapathi (2005). Putting the $S$ back in corporate social responsibility: A multilevel theory of social change in organizations. Academy of Management Review, 32(3), 836-863.

Agyei-Mensah, B. K. (2007) The relationship between corporate governance, corruption and forward-looking information disclosure: a comparative study. Corporate Governance: The International Journal of Business in Society, 17(2), 284-304.
Amorim, S. M. S. S. (2015) Influência das pressóes dos ambientes institucionais na divulgação de informaçōes ambientais das empresas dos paises do BRICS. Dissertação de mestrado. Faculdade de Economia, Administração, Atuária e Contabilidade, Universidade Federal do Ceará, Fortaleza, Ceará, Brasil.

Alsaeed, K. (2006). The association between firm-specific characteristics and disclosure: The case of Saudi Arabia. Managerial Auditing Journal, 21(5), 476-496.

Baughn, C. C., Bodie, N. L. (D.), \& Mcintosh, J. C. (2007) Corporate Social and Environmental Responsibility in Asian Countries and Other Geographical Regions. Corporate Social Responsibility and Environmental Management, No 14, 189-205.

Belkaoui, A., \& Karpik, P. G. (1989). Determinants of the Corporate Decision to Disclose Social Information. Accounting, Auditing \& Accountability Journal, 2(1), 36-51.

Boesso, G., \& Kumar, K. (2007). Drivers of corporate voluntary disclosure: A framework and empirical evidence from Italy and the United States. Accounting, Auditing \& Accountability Journal, 20(2), 269-296.

Bolacio Filho, E. S. Humor contrastivo - Brasil e Alemanha: análise de séries televisivas de uma perspectiva intercultural. (2012). (Tese de doutorado). PUC Pontifícia Universidade Católica do Rio de Janeiro. Retrieved from https://www.maxwell.vrac.puc-rio. br/20657/20657_1.PDF.

Botosan, C. A. (1997). Disclosure level and the cost of equity capital. The Accounting Review, 72(3), 323-349.

Campbell, J. L. (2007). Why would corporations behave in socially responsible ways? An institutional theory of corporate social responsibility. Academy of Management Review, 32(3), 946-967.

Cho, C. H, \& Patten, D. M. (2007). The role of environmental disclosures as tools of legitimacy: A research note. Accounting, Organizations and Society, 32(639-647).

Delmas, M., \& Toffel, M. W. (2004). Stakeholders and environmental management practice: an institutional 
framework. Business Strategy and the Environmental, Vol. 13, 209-222.

de Mascena, K., Barakat, S., Isabella, G., \& Fischmann, A. (2020). The Influence of Board Structure and Ownership Concentration on GRI Reporting. Review of Business Management, 22(3), 608-627. doi:https://doi.org/10.7819/ rbgn.v22i3.4075

Ederington, J., \& Minier, J. (2003). Is environmental policy a secondary trade barrier? An empirical analysis. Canadian Journal of Economics, 36(1), 137-154.

Federal Ministry for Economic Affairs and Energy (BMWI). (2016). Investing in Germany's and Europe's future. Retrieved from http://www.bmwi.de/EN/Topics/ Economy/priorities-for-germanys-economic-policy.html

Fischer, T. M., \& Sawczyn, A. A. (2013). The relationship between corporate social performance and corporate financial performance and the role of innovation: evidence from German listed firms. Journal of Management Control, 24(1), 27-52.

Gamerschlag, R., Möller, K., \& Verbeeten, F. (2011). Determinants of voluntary RSC disclosure: empirical evidence from Germany. Review of Managerial Science. Vol. 5, 233-262.

Global Reporting Initiative (GRI) (2017). Information: About GRI. Retrieved from <https://www.globalreporting. org/information/about-gri/Pages/default.aspx>

Gray, S. J. (1988). Towards a theory of cultural influence on the development of accounting systems internationally. Abacus, 24(1), 1-15.

Grecco, M. C. P., Milani Filho, M. A. F., Segura, L. C., Sanchez, I.-M. G., Dominguez, L. R. (2013). The voluntary disclosure of sustainable information: a comparative analysis of Spanish and Brazilian companies. Revista de Contabilidade e Organizaçóes, 7(17), 45-55.

Hofstede, G. (1983). The cultural relativity of organizational practices and theories. Journal of International Business Studies, 14(1), p. 75-89.

Hofstede Insights (2017). Country comparison. Retrieved from https://www.hofstede-insights.com/country-comparison
Intergovernmental Panel on Climate Change (IPCC). 1999. Aviation and the global atmosphere. Special Report. Published for the Intergovernmental Panel on Climate Change. Retrieved from <https://www.ipcc.ch/ $\mathrm{pdf} /$ special-reports/spm/av-en.pdf>

Ioannou, I, \& Serafeim, G. (2012). What drives corporate social performance? The role of nation level institutions. Journal of International Business Studies, 43(9), 834-864.

Jensen, J. C., \& Berg, N. (2012). Determinants of Traditional Sustainability Reporting Versus Integrated Reporting. An Institutionalist Approach. Business Strategy and the Environment, Vol. 21, 299-316.

Kolk, A. (2010). Trajectories of sustainability reporting by MNCs. Journal of World Business, 45(4), 367-374.

Kraemer, M. E. P. (2001). Contabilidade Ambiental como Sistema de Informaçôes. Contabilidade Vista e Revista, 12(3), 71-92.

Lattemann, C., Fetscherin, M., Alon I., Li S., \& Schneider, A.-M. (2009). Communication intensity in Chinese and Indian multinational companies. Corporate Governance: An International Review, 17(4), 26-442.

Li, S., Fetscherin, M., Alon I., Lattemann, C. \& Yeh, K. (2010). Corporate social responsibility in emerging markets: the importance of the governance environment. MIR: Management International Review: Journal of International Business, 50(5), 635-654.

Lim, A., \& Tsutsui, K. (2012). Globalization and commitment in corporate social responsibility: crossnational analyses of institutional and political-economy effects. American Sociological Review, 77(1), 69-98.

Marino, P. B. L. P. (2016). Influência do ambiente institucional na extensão da divulgação de informaçōes de responsabilidade social corporativa no Brasil e Canadá. Dissertação de mestrado. Universidade Federal do Ceará, Fortaleza, Ceará, Brasil.

Matten, D., \& Moon, J. (2008). "Implicit" and "explicit" RSC: A conceptual framework for a comparative understanding of corporate social responsibility. Academy of Management Review, 33(2), 404-424. 
Mayer C. (1990). Financial systems, corporate finance, and economic development. In: Hubbard G. (ed.). Asymmetric information, corporate finance and investment. 307-332. Retrieved from http://www.nber.org/chapters/ c11477.pdf.

Meireles, F. R. S. (2014). Intensidade da comunicação de responsabilidade social corporativa na América Latina: Reflexos do ambiente institucional. Dissertação de mestrado. Faculdade de Economia, Administração, Atuária e Contabilidade, Universidade Federal do Ceará, Fortaleza, Ceará, Brasil.

Neumayer, E., \& Perkins, R. (2004). What explains the uneven take-up of ISO 14001 at the global level? A panel-data analysis. Environment and Planning A, 36(5), 823-839.

Orij, R. (2010). Corporate social disclosures in the context of national cultures and stakeholder theory. Accounting, Auditing \& Accountability Journal, 23(7), $868-889$.

Orlitzky, M., Louche, C., Gond, J.-P., \& Chapple, W. (2015). Unpacking the drivers of corporate social performance: A multilevel, multistakeholder, and multimethod analysis. Journal of Business Ethics, No 144, 21-40.

Ribeiro, A. M., Bellen, H. M. V., \& Carvalho, L. N. G. (2011). Regulamentar faz diferença? O caso da evidenciação ambiental. Revista Contabilidade \& Finanças - USP, 22(56), 137-154.

Sánchez, I. M. G., Domínguez, L. R., \& Álvarez, I. G. (2011). Corporate governance and strategic information on the Internet: A study of Spanish listed companies. Accounting, Auditing \& Accountability Journal, 24(4), 471-501.

Sanchez, I. M. G., Ballesteros, B. C., \& Aceituno, J. V. F. (2016). Impact of the institutional macro context on the voluntary disclosure of RSC information. Long Range Planning, 49(1), 15-35.

Santos, S. Impacto ambiental causado pela indústria têxtil. (1997). Anais do Encontro de Engenharia da Produção - ENEGEP. Gramado, Rio Grande do Sul, Brasil, 17.
Schreck, P., \& Raithel, S. (2018). Corporate social performance, firm size, and organizational visibility: Distinct and joint effects on voluntary sustainability reporting. Business \& Society, 57(4), 742-778.

Silva, D. S. C. (2017). Pressóes institucionais na divulgação dos capitais do relato integrado. Dissertação de mestrado. Faculdade de Economia, Administração, Atuária e Contabilidade, Universidade Federal do Ceará, Fortaleza, Ceará, Brasil.

Silveira, M. L. G., \& Pfitscher, E. D. (2013). Responsabilidade socioambiental: Estudo comparativo entre empresas de energia elétrica da Região Sul do Brasil. Perspectivas em Gestão \& Conhecimento,3(2).

Soares, R., Sá de Abreu, M., Pinheiro Marino, P., \& Rebouças, S. (2020). The Effect of National Business Systems on Social and Environmental Disclosure: A Comparison between Brazil and Canada. Review of Business Management, 22(1), 29-47. doi:https://doi.org/10.7819/ rbgn.v22i1.4042

Souza, V. R., \&Ribeiro, M. S. (2004). Aplicação da contabilidade ambiental na indústria madeireira. Revista Contabilidade \& Finanças, 15(35), 54-67.

Tempel, A., \& Walgenbach, P. (2007). Global standardization of organizational forms and management practices? What new institutionalism and the business-systems approach can learn from each other. Journal of Management Studies, 44(1), 1-24.

Viana Junior, D., \& Crisóstomo, V. (2019). The Effects of Voting Ownership Concentration on Social and Environmental Disclosure: Empirical Evidence from Brazil. Review of Business Management, 21(4), 906927. doi:https://doi.org/10.7819/rbgn.v21i5.4026. Retrieved from https://rbgn.fecap.br/RBGN/article/ view/4026/pdf_1

Waddock, S. A., \& Graves, S. B. (1997). The corporate social performance-financial performance link. Strategic Management Journal, № 18, p. 303-319.

Whitley, R. (1999). Divergent capitalisms: The social structuring and change of business systems. Oxford, United Kingdom: Oxford University Press. 
World Bank. (2016). Brasil: Aspectos Gerais. Retrieved from <http://www.worldbank.org/pt/country/brazil/ overview $>$ World Economic Forum. (2018).

World Economic Forum - WEF (2018). The global competitiveness report 2017-2018. Insight Report, Geneva: WEF. Retrieved from http://www3.weforum.org/docs/ GCR2017-2018/05FullReport/TheGlobalCompetitive nessReport2017\%E2\%80\%932018.pdf.
Wronski, Pollyanna Gracy, \& Klann, Roberto Carlos. (2020). Conservadorismo Contábil e Cultura Nacional. BBR. Brazilian Business Review, 17(3), 344-361. Epub July 03, 2020. https://dx.doi.org/10.15728/bbr.2020.17.3.6

Young, S., \& Marais, M. (2012). A multi-level perspective of CSR reporting: the implications of national institutions and industry risk characteristics. Corporate Governance: An International Review, 20(5), 432-450. 


\section{Funding agency:}

CAPES - Coordenação de Aperfeiçoamento de Pessoal de Nível Superior

\section{Conflicts of interest:}

The authors have no conflicts of interest to disclose.

\section{Copyrights:}

RBGN holds the copyrights to all published contents.

\section{Plagiarism detection:}

RBGN submits all articles to plagiarism detection upon submission and after approval of the manuscript, using the software iThenticate.

\section{Authors:}

1. Karla Vanessa Nogueira Maia Amorim, M.Sc., Unifanor Wyden University Center, Fortaleza, Brazil.

E-mail: karlavnma@gmail.com

2. Marcelle Colares Oliveira, PhD., Universidade Federal do Ceará, Fortaleza, Brazil.

E-mail: marcellecolares@ufc.br

3. Manuel Salgueiro Rodrigues Júnior, PhD., Universidade Estadual do Ceará, Fortaleza, Brazil.

E-mail: msrodriguesjr@gmail.com

\section{Contribution of each author:}

Karla Vanessa Nogueira Maia Amorim: Definition of research problem; development of hypotheses or research questions (empirical studies); development of theoretical propositions (theoretical studies); theoretical framework/review of the literature; definition of methodological procedures; data collection; statistical analysis; data analysis and interpretation; critical review of manuscript; drafting of manuscript.

Marcelle Colares Oliveira: Definition of research problem; development of hypotheses or research questions (empirical studies); development of theoretical propositions (theoretical studies); theoretical framework/review of the literature; definition of methodological procedures; statistical analysis; data analysis and interpretation; critical review of manuscript; drafting of manuscript.

Manuel Salgueiro Rodrigues Júnior: Definition of research problem; statistical analysis; data analysis and interpretation; critical review of manuscript; drafting of manuscript. 